\title{
DECVRSIO MOTIFS ON THE REVERSE OF NERO'S SESTERTII (REVISITING AN OLD ISSUE)
}

\begin{abstract}
Debates among the scientific community regarding the meaning and motives for the coinage of decursio reverse motifs on Nero's sestertii have persisted for a long time. This paper aims to point to other possibilities of interpretation through the connection with concomitantly coined reverse depictions (Adlocutio coh, Annona/Ceres, congiarium).
\end{abstract}

\section{KEYWORDS: DECVRSIO, NERO, REVERSE MOTIFS, SESTERTII.}

Since the time of the Roman Republic and also later in the Empire, ${ }^{1}$ the term decursio has been defined as military manoeuvres with full equipment for the purposes of training, ${ }^{2}$ military honours during funerals of prominent generals or emperors with soldiers and cavalry circling around the bonfire, ${ }^{3}$ or false battle, in the form of a play,

1 The study results from the project: IRS - Viminacium, Roman city and legionary camp - research of the material and non-material culture of inhabitants using the modern technologies of remote detection, geophysics, GIS, digitalisation and 3D visualisation (No. 47018) - Ministry of Education and Science of the Republic of Serbia.

2 Liv. 23.35,6 (... crebro decurrere milites cogebat ...); $24.48,11$ (... decurrendo signa sequi ...); 26.51,4 (... primo die legiones in armis quattuor milium spatio decurrerunt...); 42.52,4 (... non iusto decursu tamen ...); Tac. Ann. 2.55 (... sed exercito equitum, decursibus cohortium inteeresse ...).

3 Liv. 25.17,4-5 (...armatum exercitum decucurrisse cum tripudiis Hispanorum motibusque armorum et corporum suae cuique genti adsuetis...); Verg. A. 11.187-188 (...Ter circum accensos cincti fulgentibus armis decurrere rogos ...); Tac. Ann. 2.7 (... restituit aram honorique patris princeps ipse cum legionibus decucurrit...); Suet. Claud. 1.3 (... ceterum exercitus honorarium ei tumulum excitauit, circa quem deinceps stato die quotannis miles decurreret...). between two military groups which was a kind of sport practiced in the Circus. ${ }^{4}$ It has been recorded that besides the Circus, false battles were also performed at the aforementioned funerals. ${ }^{5}$

In Roman imperial coinage the legend DECVRSIO occurs only on Nero's sestertii. These specimens (Fig. 1-3) were emitted in the mints of Rome 63-64 AD (in two variants of the legend: without S C and with S C and with three different depictions) and Lugdunum 65-67 AD (only with S C and one depiction). ${ }^{6}$ We want to

4 Liv. 44.9,3 (... iuvenes etiam quidam Romani ludicro circensi ad usum belli verso partem humillimam muri ceperunt...);RE Bd. IV.2, 2354.1-19.

5 Liv. 40.6,5 (... mos erat lustrationis sacro peracto decurrere exercitum, et divisas bifariam duas acies concurrere ad simulacrum pugnae...).

6 Gnecchi once defined sestertii without the S C mark as module 2 medallions, with diameters from $35-36 \mathrm{~mm}$ and weight from 26-28 gr ( $c f$. Gnecchi 1912: 5, nos. 15-19). After decades-long debate, this determination was rejected and it has been concluded that specimens without $\mathrm{S} \mathrm{C}$ in the reverse legend belong to the regular emissions (of sestertii) of the mint of Rome. For detailed discussion with a quoted bibliography $c f$. MacDowall 1979: 55-60; RIC I: 137-139. 
note that this reverse motif, in both mints and in The presence of the reverse types on sestertii in different emissions, always occurs with the types some emissions of the mints of Rome and LugduADLOCVT COH, ANNONA AVGVSTI CERES, num are shown in the following tables in order to CONG I - DAT - POP or CONG II - DAT - POP. be presented more clearly (Table 1, 2).

\begin{tabular}{|c|c|c|}
\hline RIC I no./nos. & Reverse legend & Reverse types \\
\hline \multicolumn{3}{|c|}{ Rome, Issue 2, $63 \mathrm{AD}$} \\
\hline $95-97$ & ADLOCVT COH & $\begin{array}{l}\text { Nero with praetorian perfect on plat- } \\
\text { form on right, addressing three soldiers. } \\
\text { In background, pillared building below } \\
\text { battlemented crescent-shaped structure } \\
\text { (the praetorian camp?). }\end{array}$ \\
\hline $98-99$ & ANNONA AVGVSTI CERES & $\begin{array}{l}\text { Ceres and Annona, between them mo- } \\
\text { dius on garlanded altar; behind, ship's } \\
\text { stern. }\end{array}$ \\
\hline $100-101$ & CONG II - DAT - POP (R) & Cogiarium, platform on left \\
\hline 102 & CONG II - DAT - POP & Cogiarium, platform on right \\
\hline $103-104$ & DECVRSIO (ex) & $\begin{array}{l}\text { Nero, bare-headed, cuirassed, and with } \\
\text { cloak floating free, prancing right on } \\
\text { horseback; in right hand holding spear; } \\
\text { beyond and behind him, mounted } \\
\text { soldier prancing left with vexillum held } \\
\text { over right shoulder (RIC I, type 11). }\end{array}$ \\
\hline $105-108$ & DECVRSIO (ex) & $\begin{array}{l}\text { Nero bare-headed, cuirassed, and with } \\
\text { cloak floating free, prancing right on } \\
\text { horseback, in right hand holding spear; } \\
\text { foot-solder in front advancing right } \\
\text { looking back, in right hand holding up } \\
\text { vexillum, and with a second foot-sol- } \\
\text { dier, helmeted, running behind the } \\
\text { horse (RIC I, type 12). }\end{array}$ \\
\hline \multicolumn{3}{|c|}{ Rome, Issue 3, $64 \mathrm{AD}$} \\
\hline $130-136$ & ADLOCVT COH S C & Same as nos. 95-97 \\
\hline $137-142$ & $\begin{array}{l}\text { ANNONA AVGVSTI CERES } \\
\text { S C }\end{array}$ & Same as nos. 98-99 \\
\hline $151-155$ & $\begin{array}{l}\text { CONG I - DAT - POP } \\
\mathrm{SC}(\mathrm{ex})\end{array}$ & Cogiarium, platform on left \\
\hline $156-157$ & $\begin{array}{l}\text { CONG II - DAT - POP } \\
\mathrm{SC}(\mathrm{ex})\end{array}$ & Cogiarium, platform on left \\
\hline $158-162$ & $\begin{array}{l}\text { CONG II - DAT - POP } \\
\text { SC (ex) }\end{array}$ & Cogiarium, platform on right \\
\hline
\end{tabular}




\begin{tabular}{|l|l|l|}
\hline RIC I no./nos. & Reverse legend & Reverse types \\
\hline $163-166$ & DECVRSIO (ex) \\
S C (left and right) & $\begin{array}{l}\text { Nero, bare-headed, cuirassed, and with } \\
\text { cloak floating free, prancing left on } \\
\text { horseback, in right hand holding spear; } \\
\text { beyond and behind him, mounted } \\
\text { soldier prancing left with vexillum held } \\
\text { over right shoulder (RIC I, type 10). }\end{array}$ \\
\hline $143-150$ & S C (left and right) & Triumphal arch \\
\hline $178-183$ & AVGVSTI POR OST S C & Harbour of Ostia \\
\hline
\end{tabular}

Table 1 - Presence of Nero reverse types on sestertii of the mint of Rome

\begin{tabular}{|c|c|c|}
\hline RIC I no./nos. & Reverse legend & Reverse types \\
\hline \multicolumn{3}{|c|}{ Lugdunum, Issue 1 (= Issue 3 of Rome), $64 \mathrm{AD}$} \\
\hline 371 & ADLOCVT COH S C & Same as nos. 95-97 \\
\hline 372 & $\begin{array}{l}\text { ANNONA AVGVSTI CERES } \\
\text { S C }\end{array}$ & Same as nos. 98-99 \\
\hline \multicolumn{3}{|c|}{ Lugdunum, Issue 2 (= Issue 3 of Rome), $64 \mathrm{AD}$} \\
\hline $386-388$ & ADLOCVT COH S C & Same as nos. $95-97$ \\
\hline $389-391$ & $\begin{array}{l}\text { ANNONA AVGVSTI CERES } \\
\text { S C }\end{array}$ & Same as nos. $98-99$ \\
\hline 394 & $\begin{array}{l}\text { CONG I - DAT - POP } \\
\text { SC (ex) }\end{array}$ & Cogiarium, platform on left \\
\hline $395-397$ & $\begin{array}{l}\text { DECVRSIO (ex) } \\
\text { S C (left and right) }\end{array}$ & Same as nos. 103-104 (RIC I, type 11). \\
\hline $392-393$ & $\mathrm{~S} \mathrm{C}$ (left and right) & Triumphal arch \\
\hline 398 & $\begin{array}{l}\text { ROMA (ex) } \\
\text { S C (left and right) }\end{array}$ & Roma with Victory and parazonium \\
\hline \multicolumn{3}{|c|}{ Lugdunum, Issue 3 (= Issue 3 and 4 of Rome), $65 \mathrm{AD}$} \\
\hline 429 & ADLOCVT COH S C & Same as nos. $95-97$ \\
\hline $430-431$ & $\begin{array}{l}\text { ANNONA AVGVSTI CERES } \\
\text { S C }\end{array}$ & Same as nos. $98-99$ \\
\hline $434-435$ & $\begin{array}{l}\text { CONG I - DAT - POP } \\
\text { SC (ex) }\end{array}$ & Cogiarium, platform on left \\
\hline $436-437$ & $\begin{array}{l}\text { DECVRSIO (ex) } \\
\text { S C (left and right) }\end{array}$ & Same as nos. 103-104 (RIC I, type 11). \\
\hline
\end{tabular}




\begin{tabular}{|c|c|c|}
\hline RIC I no./nos. & Reverse legend & Reverse types \\
\hline $432-433$ & S C (left and right) & Triumphal arch \\
\hline $438-439$ & $\begin{array}{l}\text { PACE P R TERRA MARIQ } \\
\text { PARTA IANVM CLVSIT } \\
\text { S C }\end{array}$ & Temple of Janus; door to right. \\
\hline $440-441$ & AVGVSTI POR OST S C & Harbour of Ostia \\
\hline $442-443$ & $\begin{array}{l}\text { ROMA (ex) } \\
\text { S C (left and right) }\end{array}$ & Roma with Victory and parazonium \\
\hline \multicolumn{3}{|c|}{ Lugdunum, Issue 4 (= Issue 5 of Rome), $66 \mathrm{AD}$} \\
\hline $498-492$ & ADLOCVT COH S C & Same as nos. $95-97$ \\
\hline $493-497$ & $\begin{array}{l}\text { ANNONA AVGVSTI CERES } \\
\text { S C }\end{array}$ & Same as nos. 98-99 \\
\hline $501-504$ & $\begin{array}{l}\text { CONG I - DAT - POP } \\
\text { SC (ex) }\end{array}$ & Cogiarium, platform on left \\
\hline $505-506$ & $\begin{array}{l}\text { CONG II - DAT - POP } \\
\text { SC (ex) }\end{array}$ & Cogiarium, platform on right \\
\hline $507-509$ & $\begin{array}{l}\text { DECVRSIO (ex) } \\
\text { S C (left and right) }\end{array}$ & Same as nos. 103-104 (RIC I, type 11). \\
\hline $498-500$ & S C (left and right) & Triumphal arch \\
\hline $510-512$ & $\begin{array}{l}\text { PACE P R TERRA MARIQ } \\
\text { PARTA IANVM CLVSIT } \\
\text { S C }\end{array}$ & Temple of Janus; door to right. \\
\hline $513-514$ & AVGVSTI POR OST S C & Harbour of Ostia \\
\hline $515-517$ & $\begin{array}{l}\text { ROMA (ex) } \\
\text { S C (left and right) }\end{array}$ & Roma with Victory and parazonium \\
\hline \multicolumn{3}{|c|}{ Lugdunum, Issue 5 (= Issue 6 of Rome), $67 \mathrm{AD}$} \\
\hline $564-565$ & ADLOCVT COH S C & Same as nos. 95-97 \\
\hline $566-572$ & $\begin{array}{l}\text { ANNONA AVGVSTI CERES } \\
\text { S C }\end{array}$ & Same as nos. 98-99 \\
\hline 576 & $\begin{array}{l}\text { CONG II - DAT - POP } \\
\text { SC (ex) }\end{array}$ & Cogiarium, platform on left \\
\hline $577-582$ & $\begin{array}{l}\text { DECVRSIO (ex) } \\
\text { S C (left and right) }\end{array}$ & Same as nos. 103-104 (RIC I, type 11). \\
\hline $573-575$ & S C (left and right) & Triumphal arch \\
\hline $583-585$ & $\begin{array}{l}\text { PACE P R TERRA MARIQ } \\
\text { PARTA IANVM CLVSIT } \\
\text { S C }\end{array}$ & Temple of Janus; door to right. \\
\hline
\end{tabular}




\begin{tabular}{|l|l|l|}
\hline RIC I no./nos. & Reverse legend & Reverse types \\
\hline $586-589$ & AVGVSTI POR OST S C & Harbour of Ostia \\
\hline $590-594$ & $\begin{array}{l}\text { ROMA (ex) } \\
\text { S C (left and right) }\end{array}$ & Roma with Victory and parazonium \\
\hline
\end{tabular}

Table 2 - Presence of Nero reverse types on sestertii of the mint of Lugdunum

From the previous tables it is clearer that the two groups of reverse motifs were coined together only in two emissions in the mint of Rome and four emissions in the mint of Lugdunum. On the one side there are decursio and adlocutio motifs, intended as propaganda directed to the Praetorian Guard and reflecting Nero's constant need to secure their support. On the other side the motifs Annona/Ceres and congiarium represent Nero's wish

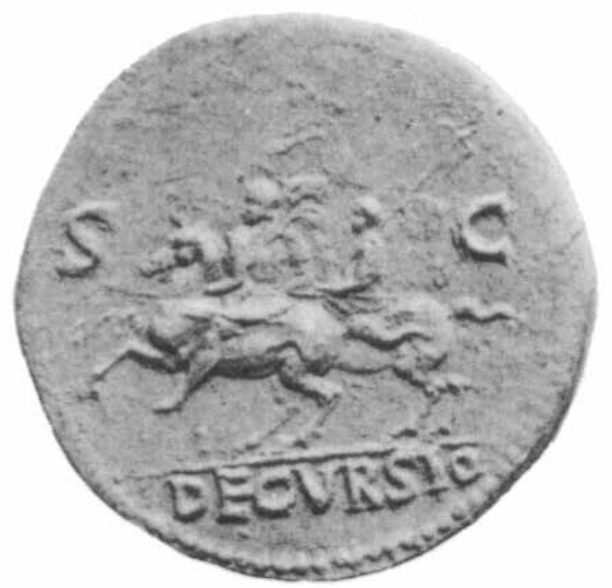

Fig. 1 RIC I, type 10 (according to BMC I, Pl. 42.4; enlarged) to assure an adequate grain supply for Rome and the sharing of it with the civilian population. The exception is the first emission of the Lugdunum mint in which all four types are not present, but only two are. However, in this case one type from both groups of motifs (adlocutio and Annona/Ceres) is also present. Besides the aforementioned, in some emissions four more types of reverse depictions (Triumphal Arch, the Port of Ostia, Roma

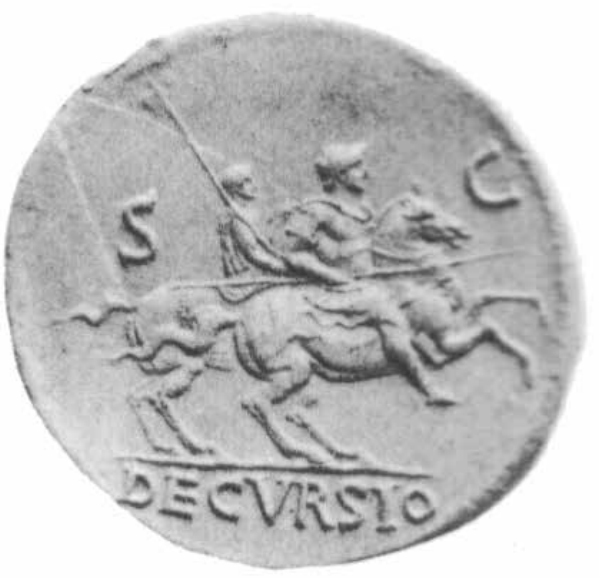

Fig. 2 RIC I, type 11 (according to BMC I, P1. 42.3; enlarged)

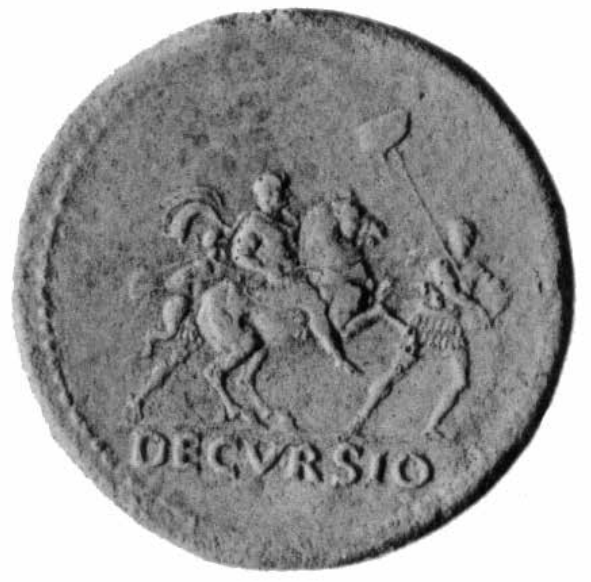

Fig. 3 RIC I, type 12 (according to Gnecchi III, Tav. 141.8; enlarged) 
and the Temple of Janus) appear, which has no impact on our debate on decursio motifs.

Different interpretations of the decursio motifs have been presented since 1920 (Sydenham 1920: 113; Sutherland 1974: 169; Griffin 1984: 121; Smith 2000: 282-289), and have been connected with other games organised by Nero (Neronia Ludi Quinquennales), with the permission from Nero that the public can attend military training on the Campus Martius, with a showing of the emperor leading the military procession in the Circus, or with motifs illustrating the Troy Games (Lusus Troiae), etc. We start our debate with the solution offered by Sutherland (Sutherland 1974: 169), with whom we agree, who identified the soldiers in Nero's entourage as members of the Praetorian Guard.

The Praetorian cohorts were organised during the Punic Wars, as a personal entourage of consuls, consisting of auxiliary troops. These equites extra-ordinarii delecti were placed at Porta Praetoria in legionary barracks. Since Scipio Africanus, the Praetorian cohorts were formed by selecting the strongest soldiers (fortissimi), to whom an allowance was provided that was six times higher than that of the legionnaires (Rossi 1967: 20). With the beginning of the Principate and the reign of Octavian Augustus, issues related to military organisation and military service were arranged in a new way. A reduced number of legions were deployed along the borders, the service became professional and the path of military careers, payment and reward were defined. Augustus established nine Praetorian cohorts, three of them were settled in Rome, and the rest were deployed throughout Italy (Suet. Aug. 49). Service in them was considered a privilege because they represented the Imperial Guard. The presence of the Praetorians in Rome, their privileged status, as well as the position of the Praetorian prefect who was close to the emperors soon opened the possibility to them to become the decisive factor in the election of a new Princeps.

The immediate successors to Augustus already started to rely heavily on the Praetorians. The re- verse motif adlocutio cohortium occurs for the first time in Caligula's emissions, which were coined each year during his rule (RIC I: 110-111, nos. 32, $40,48){ }^{7}$ Nevertheless, the Praetorians took part in the conspiracy and murder of Caligula (Suet Gaius 56), as well as in the proclamation of Claudius as the Princeps. After that, Claudius paid 15,000 sestertii to each of the Praetorians and, thus, became the first emperor to gift money for his election (Suet Claud 10). The Praetorians became an important factor in political life, openly showing their attitude towards the candidates for the purple, and their presence in Rome favoured that.

After Caligula, the adlocutio cohortium reverse motif appears in the aforementioned emissions of Nero (Table 1, 2). In the description of the reverse depiction, a structure with a crescentshaped vault in the background is mentioned (RIC I: 156, type 1; Fig. 4), for which, with certain reservations, it is assumed to be the Praetorian camp. On the specimen published by Gnecchi as a medallion without S C (Fig. 5) (cf. supra ref. 5) a structure with a saddle roof is clearly visible in the background. In RIC I only the first variant with a crescent-shaped vault is mentioned, but in his discussion Rossi separates them as variants $\mathrm{A}$ and B (Rossi 1967: 28).

The same author compared the details of the adlocutio cohortium reverse depictions of Caligula and Nero and came to conclusions regarding the affiliation of the presented soldiers with specific formations (Rossi 1967:15-38). Based on the clothes, armour and military insignia on Caligula's specimens, Rossi concluded that Praetorians were depicted. ${ }^{8}$ According to that author, depictions on Nero's specimens show a series of various and unique details, which define them as cohors Germanorum corporis custodies and, as such, they represent a unique numismatic docu-

7 Dio Cassius (Dio Cass. LIX.2.1) mentions the visit of Caligula and the Senate to the Praetorians at the beginning of his reign. On that occasion he assigned 1,000 sestertii to each of them.

8 Ritter 1971:81 and Smith 2000: 284. also agree with his opinion. 


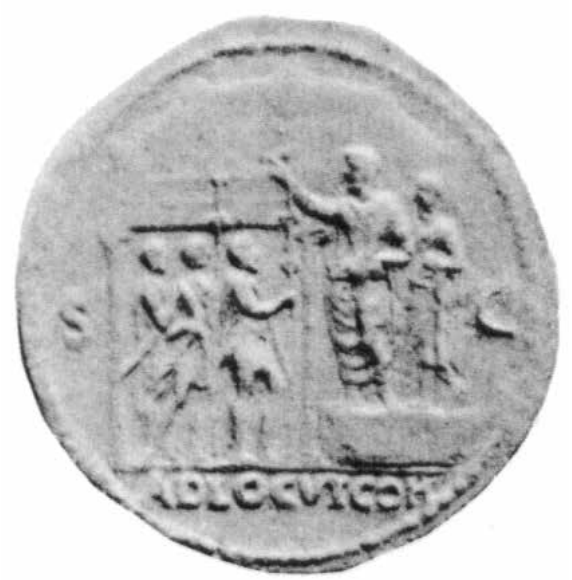

Fig. 4 RIC I, type 10 (according to BMC I, Pl. 41.5; enlarged)

mented depiction of the auxiliary in Roman service (Rossi 1967: 38).

Corporis custodes represented, unlike the Praetorians, a more personal entourage of the emperor. Ethnically they belonged to the Germanic tribes (Batavi) and they had no personal or political connections with Rome. Augustus inherited the custom of having Germanic peoples in his personal entourage from Caesar (Caesar, De bello Gallico 7.13.1), although he disbanded them after Varus's defeat (Suet Aug. 49). Caligula had them again in his closest entourage (Suet. Gaius 43, 58), as did Nero, who trusted them more because they were foreigners (Tac. Ann. 15.58), but they were definitely disbanded by Galba (Suet. Galba 12).

Therefore, at the time of Nero, a certain dictatorship of the Praetorians was already established in the election of a Princeps, when they did not hesitate to even commit murder. In such an atmosphere, the Princeps should not have ignored the needs of the Praetorians, but, as we have seen in the previous discussion, he also had his own more personal Germanic guard whom he trusted more. If we accept that Nero on the adlocutio types refers to his Germanic guard, then on the decursio types the Praetorians must have been shown, as Sutherland already concluded (Sutherland 1974: 169).

In the attempts to interpret the decursio types, it was generally believed that they have a promi-

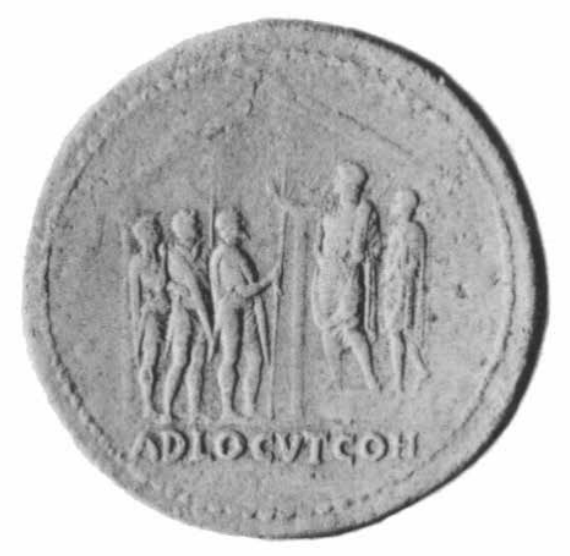

Fig. 5 RIC I, type 11 (according to Gnecchi III, Tav. 141.5 ; enlarged)

nent militaristic propaganda, which is in contrast to Nero's character and theatrical preferences, which were, according to the testimony of historical sources, considered disorderly. Taking this into consideration, Smith assumed as one of the possibilities that Nero's entourage on the decursio types are not real soldiers but actors and that the depicted scenes have no military character, but that they rather present a form of theatre (Smith 2000: 284). Pointing to the sources confirming Nero's affection for Trojans and his love of horses, the same author suggested that one aspect of the legend of Troy, lusus Troiae (Ludus Troiae), was depicted on the decursio types.

Virgil described Lusus Troiae in detail in the Aeneid (Verg. Aeneid V. 545-603). It represents a staged battle that peaks in the games representing the commemoration of the first anniversary of the death of Anchises. This chivalrous game was restored by Caesar as a part of the propaganda that the family of the gens Julia descended from Aeneas (Suet. Divus Iulius 39).

The game included various equestrian games which required special skills, and they were performed by young Roman men from respectable families. Continuing this tradition, Augustus organised the Troy game several times (Suet. $\mathrm{Di}$ vus Aug. 43; Dio Cass. 51.22.4; 54.26.1), and the young Tiberius took part in one of them (Suet. 
Tib. 6). Caligula organised the Troy games in the Circus (Suet. Gaius 18), as did Claudius on the occasion of the centenary games (Suet. Claud 21). In these games, held in $47 \mathrm{AD}$, Nero participated successfully as a still immature boy, and received great applause (Suet. Nero 7; Tac. Ann 11.11).

The Troy games had been organised in the early Principate during the consecration of temples, imperial funerals, as well as during major celebrations in the Circus, etc. Trying to find a reason for performing a Troy game involving Nero, which would then be depicted on sestertii, Smith proposed the funeral of Nero's daughter Claudia in the year $63 \mathrm{AD}$ (Smith 2000: 287). ${ }^{9}$ The main problem, according to Smith, is that at that time, Nero was 26 years old, and that, as a rule, young men took part in the Troy game years before they wore a toga virilis. Nero's participation, regardless of his age, seems quite possible to the author, taking into account the nature of his personality, love of performances, of acting and of horses (Smith 2000: 289).

We cannot agree with this interpretation for a number of reasons. It seems highly unlikely that the performance of the Troy games at the funeral of Nero's daughter, who lived only four months, was the reason for the appearance of decursio types over five years (from 63-67 AD). The birth of Claudia was recorded in the sources (Suet. Nero 35), as was Nero's joy about it, as well as the games that were organised, the statues that were laid, the temple of fertility that was about to be built, etc. Tacitus also describes Nero's mourning after the death of his daughter, who he had deified: "Nero's grief, like his joy was without bounds and measure." (Tac. Ann. 15.23). Regardless of the detailed descriptions of all celebrations and actions that were performed after the birth of Claudia, Tacitus does not mention her funeral at all, but in his presentation shifts to the Parthian question and preparations for the arrival of Tiridates in Rome

9 Claudia was the daughter of Nero and Poppaea Sabina. She was born on January 21, $63 \mathrm{AD}$ and died as soon as April or May of the same year (cf. Kienast 2010: 100; Suet. Nero 35; Tac. Ann. 15.23). in the same year. In addition, according to Smith, the soldiers in the entourage were actors who followed Nero to the staged battles or lusus Troiae. Thereby, he finds justification for Nero's participation in the games, taking into consideration his age (26), which was not in accordance with the rules of the games. The author finds the argument in Tacitus's descriptions of his reign as "...as a deceptive adolescnece, and it retained a childish quality to his death..." (Smith 2000: 287). ${ }^{10}$

The root of our disagreement with Smith's conclusions that this is an illustration of the Troy games on the occasion of Claudia's funeral is based, among other things, on the fact that in the same sources the term decursio clearly differs from ludus Troiae. The fact that the staged battle that was practiced in the Circus as decursio is a different manifestation than the Troy games that also could have taken place in the Circus. ${ }^{11}$ In the sources these two terms do not appear together (cf. supra ref. 1-4), but separately and clearly emphasised. It turns out that these close manifestations cannot equate.

Besides, if our thoughts would go in this direction, which is not the case, more arguments would be found for the appearance of decursio types in relation to Neronia (60 and $65 \mathrm{AD}$ ). The games that Nero designed in honour of his reign were conceptualised according to the Greek models, and consisted of musical, gymnastic and equestrian parts (Suet. Nero 12; Tac. Ann. 14.20-21; Cass. Dio LXI.21). This would better chronologically justify the appearance of the decursio types on the sestertii (63-67 AD).

It is clear that with this discussion the question of the decursio type's appearance in Nero coinage

10 The truth is that in his conclusion Smith states that the presented idea is not without problems, but that it seems much more acceptable than the previously proposed solutions ( $c f$. Smith 2000: 288)

11 Tacitus, for example, uses the term decursibus (...sed exercitio equitum, decursibus cohortium interesse...; $c f$. Tac. Ann. 2.55) and ludicrum Troiae (...cum pueri nobiles equis ludicrum Troiae...; cf. Tac. Ann. 11.11), as decursio could also have been performed during funerals. ( $c f$. supra ref. 4). 
will not be solved. Our intention is to point out some lack of logic in the earlier interpretations. We tend to look for the explanation in entirely practical reasons, unrelated to the intimate nature or character of Nero, which caused his deranged acts that were documented. Historical sources are full of such descriptions of his behaviour, which logically leads modern researchers to seek in them the reasons for the various consequences. No matter how disturbed Nero's personality really was, he still ruled for 14 years. Behind the Princeps of the early Principate, there was a complex state apparatus, with an elaborate hierarchy. An army of people governed the state and, among other things, took care of coinage and the propaganda effects when choosing its types. If Nero's personal influence in the choice of reverse types can be observed, this would only refer to a reverse depiction without the associated legend, Nero as Apollo (Nero as Apollo Chitaroedus). By analysing other reverse types, we find only those who propagate the achievements of the reign, as in the case of the former or the latter Princepses (Adlocutio, Annona, congiarium, triumphal arch, Genius, Temple of Janus, market, port, Roma, Victoria, etc...).

Here we return to our initial observation, that the minting of certain types was a must, as seen in the emissions of the Roman and Lugdunum mints. The official propaganda policy in the period from 63-67 AD was primarily focused on the emphasis of good relationships with the Praetorians and the Emperor's personal guard (adlocutio and decursio types), as well as in the preservation of peace in the capital, which was the result of a regular supply of grain to the civilian population (congiarium and Annona/Ceres types, the Port of Ostia). The types on sestertii, which appear alongside the above-mentioned, are related to current external or internal political circumstances (the Temple of Janus, Victoria and the Triumphal arch, Roma). In that regard, the decursio types should, in the sense of propaganda, officially demonstrate and support the closeness and good relationships of the Princeps with the Praetorians. In comparison with pre- vious recent experiences, this was quite desirable for any Princeps, even Nero.

The two isolated groups of reverse depictions on Nero's sestertii had the goal of having a propaganda impact on two core supporting elements of his rule - the Praetorians and the risky mass of the civilian population in the capital. In our opinion, the decursio types (as well as adlocutio, congiarium, Annona and Ceres) do not need to be associated with the personal characteristics of the Princeps in interpretations, but with the official propaganda policy, which ultimately aimed to keep Nero, as an offspring of the Augustus lineage, ruling as long as possible.

This is also supported by the historical facts. The privileged position of the Praetorians and their high-handedness shown in the election of the Principes during the early Principate led to the discontent of the provincial legions who were proclaiming their pretenders, which ended with the outbreak of the civil war in $68 \mathrm{AD}$ and resulted in the end of the Julio-Claudian dynasty. After that, the influence of the Praetorians in the election of a Princeps was only occasionally expressed. It is known that their pressure was decisive in Nerva's selection of Trajan as his heir (Cass. Dio LXVIII.3-4), and in the last but also biggest incident, the Praetorians selling the state to Didius Julianus at the auction they organised (Cass. Dio LXXIV.1). As the historical and political circumstances changed, the influence of military formations in the election of a new emperor also changed. This privilege was acquired by the Danube Legions in the middle of the $3^{\text {rd }}$ century, primarily because of the shift in the focus of military operations into these areas and the decisive role that they had in the defence of the Empire from the ever-growing barbarian threat.

As the previous researchers of Nero's decursio types have already concluded, this question remains open for future debate and possible interpretations. Our paper is a modest contribution to this debate. 


\section{$* * *$}

Arheologija i prirodne nauke (Archaeology and Science) is an Open Access Journal. All articles can be downloaded free of charge and used in accordance with the licence Creative Commons - Attribution-NonCommercial-NoDerivs 3.0 Serbia (https://creativecommons.org/licenses/bync-nd/3.0/rs/.

Časopis Arheologija i prirodne nauke je dostupan u režimu otvorenog pristupa. Članci objavljeni $\mathrm{u}$ časopisu mogu se besplatno preuzeti sa sajta $\mathrm{i}$ koristiti u skladu sa licencom Creative Commons - Autorstvo-Nekomercijalno-Bez prerada 3.0 Srbija (https://creativecommons.org/licenses/bync-nd/3.0/rs/.

\section{BIBLIOGRAPHY}

\section{Ancient sources:}

\section{Caesar, De bello Gallico}

C. Julius Caesar. C. Iuli Commentarii Rerum in Gallia Gestarum VII A. Hirti Commentarius VII. T. Rice Holmes. Oxonii. e Typographeo Clarendoniano. 1914. Scriptorum Classicorum Bibliotheca Oxoniensis.

\section{Cass. Dio. $=$ Cassius Dio}

Roman History, english ed. (translation by E. Cary), Cambridge Mass. 1914: Harvard Univerisy Press.

\section{Liv. $=$ Titus Livius, latin}

Ab urbe condita libri, latin ed. (translation by $\mathrm{M}$. Weissenborn), Leipzig 1911: Teubner

\section{Liv. $=$ Titus Livius, english}

History of Rome, english ed. (translation by Canon Roberts), New York 1912: E. P. Dutton and Co.

\section{Suet. $=$ C. Suetonius Tranquillus, latin}

De Vita Caesarum, latin ed. (translation by $\mathrm{M}$. Ihm), Stutgardiae 1993: B.G. Teubneri.

Suet. = Gaj Svetonije Trankvil

Dvanaest rimskih careva, hrvatsko izdanje (prevod S. Hosu), Rijeka 1978: Naprijed.

Tac. Ann. $=$ Cornelius Tacitus, latin

Annales ab excessu divi Augusti, latin ed. (translation by C.D. Fisher), Oxford 1906: Clarendon Press.

\section{Tac. Ann. = Корнелије Тацит}

Анали, српско издање (превод Љ. Црепајац), Београд 1970: Спрска књижевна задруга.

\section{Vergil. A. = P. Vergilius Maro, latin}

Aeneid, latin ed. (translation by J.B. Greenough), Boston 1900: Ginn \& Co.

\section{Vergil. A. $=$ P. Vergilius Maro, english}

Aeneid, english ed. (translation by T. C. Williams), Boston 1910: Houghton Mifflin Co.

\section{Contemporary Literature:}

\section{BMC I, Mattingly H. 1923}

Coins of the Roman Empire in the British Museum I, London, 1923: British Museum.

\section{Gnecchi F. 1912}

I Medaglioni Romani, Vol. III, Bronzo, Milano, 1912: Hoepli.

\section{Griffin M.T 1984}

Nero: The end of a Dynasty, London 1984: Batsford.

Kienast D. 2010

Römische Kaisertabelle, 4. Auflage, Darmstadt 2010: WBG.

Mac Dowall D.W. 1979

Western Coinages of Nero, New York 1978: American Numismatic Society.

RIC I, Sutherland C.H.V. and Carson R.A.G. 1984

The Roman Imperial Coinage, Vol. I, London 1984: Spink and Son Ltd. 
Rossi L. 1967

La guardia Pretoriana e Germanica nella monetazione Gulio - Claudia, Rivista italiana di numismatica LXIX: 15-38.

Smith D.R. 2000

The DECVRSIO Sestertius Types of Nero and the Lusus Troiae, The Numismatic Chronicle, Vol. 160: 282-289.

Sutherland C.H.V. 1974

Roman coins, London 1974: Barrie\&Jenkins.

Sydenham E.A 1920

The Coinage of Nero, London 1920: Spink and Son Ltd.

\section{REZIME}

DECVRSIO REVESNI MOTIVI NA SESTERCIJUSIMA NERONA (JOŠ JEDNOM O STAROM PROBLEMU)

\section{KLJUČNE REČI: DECVRSIO, NERON, REVERS- NI MOTIVI, SESTERCIJI.}

Od vremena rimske republike a i kasnije u carstvu, termin decursio označavao je manevre vojske pod punom opremom u cilju treninga, vojničku počast prilikom sahrana istaknnutih generala ili careva pri kojoj su vojnici i konjanici kružili oko lomače, ili lažnu bitku, u formi predstave, između dve vojne skupine koje su predstavljale vrstu sporta upražnjavanu u cirkusu. Zabeleženo je da se lažna bitka, osim u cirkusu, izvodila i prilikom pomenutih sahrana.

$\mathrm{U}$ rimskom imperijalnom kovanju legenda DECVRSIO pojavljuje se jedino na sestercijusima Nerona. Ovi primerci (Fig. 1-3) emitovani su u kovnicama Rim 63-64 AD (u dve varijante legende: bez S C i sa S C i tri različite predstave) i Lugdunum 65-67 AD (samo sa S C i jednom predstavom. Želimo da skenemo pažnju kako se ovaj reversni motiv, u obe kovnice i u različitim emisijama, pojavljuje uvek sa tipovima $\mathrm{AD}$ LOCVT COH, ANNONA AVGVSTI CERES, CONG I - DAT - POP ili CONG II - DAT - POP. Motivi decursio i adlocutio, bili su u svojoj propagandnoj nameri usmereni na pretorijansku gardu i stalnu potrebu Nerona da osigura njihovu podršku. Sa druge strane motivi Anona/Cerera i congiarium, odražavaju Neronovu želju za adekvatnim snabdevanjem Rima žitom i podele civilnom stanovništvu.

Različite interpretacije decursio motiva su iznete počev od 1920. g. pri tome su povezivane sa drugim Neronovim igrama (Neronia - Ludi Quinquennales), sa Neronovom dozvolom da javnost prisustvuje vojnim vežbama na Marsovom polju, da prikazuju cara koji predvodi vojnu procesiju u Cirkusu, ili da su ovi motivi ilustracija Trojanskih igara (Lusus Troiae), itd.

Dve izdvojene grupe reversnih predstava na sestercijusima Nerona, imale su za cilj da praopagandno utiču na dva glavna oslonca njegove vladavine - pretorijance i rizičnu masu civilnog stanovništva u prestonici. Po našem mišljenju, decursio tipovi (kao i adlocutio, congiarium, Anona i Cerera) ne treba u interpretacijama povezivati sa ličnim karakternim osobinama princepsa, već sa oficijelnom propagandnom politikom, koja je u krajnjoj instanci imala za cilj da što duže održi Nerona na vlasti, kao izdanka Avgustove loze. 